\title{
VISI KOSMOPOLITANISME ISLAM JARINGAN INTELEKTUAL MUDA MUHAMMADIYAH
}

\section{- Hasnan Bachtiar, Moh. Nurhakim dan Haeri Fadly}

Universitas Muhammadiyah Malang, Indonesia

Email: bachtiaar@umm.ac.id

\begin{abstract}
Abstrak
Penelitian ini berupaya untuk mendiagnosa visi kosmopolitanisme Islam yang terdapat dalam peran Jaringan Intelektual Muda Muhammadiyah (JIMM). Melalui perspektif analisis sosiologi pengetahuan Karl Mannhemian, didapati bahwa JIMM berdiri di atas nalar intelektual di antara berbagai wacana humanitas dan ide-ide, seperti pluralisme, multikulturalisme, nasionalisme kebinekaan dan kosmopolitanisme. Elaborasi berbagai diskursus dan ide tersebut sengaja digelorakan dalam rangka mengasah rasa keadilan sosial dan kemanusiaan, sebagai umat bangsa dunia yang satu. Elaborasi ini adalah upaya dakwah untuk menjadi pemenang di tengah konstelasi peradaban global. Untuk mencapainya, JIMM memiliki fondasi pemikiran yang terintrepretasikan pada tiga langkah, di antaranya; Islam progresif, liberasi sosial and aktivisme sejarah. Di era kontemporer seperti saat ini, untuk menghadapai berbagai konteks masyarakat Muslim yang beragam, maka kosmopolitanisme Islam JIMM berupaya untuk mengisi perjuangan mereka melalui berbagai agenda internasionalisasi Islam berkemajuan dan Islam Indonesia.
\end{abstract}

Kata Kunci: JIMM, Islam Berkemajuan, Kosmopolitanisme Islam, dan Internasionalisasi 


\section{Pendahuluan}

"Para pembaca yang mau menyimak ekspresi pemikiran intelektual muda Muhammadiyah ini, akan memiliki kesan bahwa dinamika intelektual itu telah terjadi dalam kultur Muhammadiyah sendiri, kalau tidak boleh dibilang telah terjadi cikal bakal pemberontakan intelektual yang sesungguhnya mencemaskan bagi mereka yang merasa ke-Islamannya telah tenang dengan melakukan kesalehan ritual serta pengamalan bentuk-bentuk kemurnian beribadah. Saya tidak tahu, bagaimana membayangkan di masa depan pengaruh anak-anak muda ini, tapi yang pasti bahwa berbgai pernyataan intelektual yang muncul dari banyak tulisan mereka sepertinya merupakan pencarian tiada henti." 1

Tulisan ini ingin menjelaskan tentang bagaimana konstruksi visi kosmopolitanisme Islam di lingkungan Jaringan Intelektual Muda Muhammadiyah (JIMM). Dengan demikian, di saat yang sama, ini merupakan sebuah kajian yang menaruh perhatian terhadap suatu pencapaian intelektual JIMM, yang tengah terlibat di dalam proses pergulatan paradigmatik (baik di dalam ranah pemikiran keagamaan, filsafat dan kebudayaan) di lingkungannya sendiri.

Tujuan utama kajian ini ingin menguraikan posisi intelektualitas JIMM di hadapan berbagai paradigma sosial humaniora, khususnya yang berkaitan dengan bermacam wacana dan ide kemanusiaan kontemporer. Misalnya, bagaimana reaksi, penerimaan dan pergumulan intelektual JIMM ketika berhadapan dengan konsep kemanusiaan mutakhir, seperti pluralisme, multikulturalisme, nasionalisme kebhinekaan dan kosmopolitanisme, atau bahkan JIMM sendiri yang memiliki elaborasi khusus mengenai ide yang satu dengan yang lain.

Dengan mengetahui posisi intelektual JIMM di tengah berbagai ide kemanusiaan mutakhir, maka akan terungkap perkembangan pemikiran di lingkungan intelektual muda Muhammadiyah. Karena itu, kajian ini bukan sekedar bersifat deskriptif-rekonstruktif, namun juga diagnostik. Hasil diagnosa yang diungkap berdasarkan kajian ini akan memberikan informasi akademik yang cukup untuk mempertimbangkan corak intelektualisme Muhammadiyah, khususnya di masa depan. Persoalan corak intelektualisme ini juga akan sedikit disinggung pada bagian akhir kajian ini, untuk menjelaskan secara lebih jernih, ke mana orientasi kajian ini digulirkan.

Moeslim Abdurrahman, "Memperebutkan Kebenaran Firman," Muhammadiyah Progressif: Manifesto Pemikiran Kaum Muda (Jakarta: JIMM dan LESFI, 2007), h. xxiii. 
Sebagai kajian pemikiran dan filsafat yang merambah disiplin ilmu sosial dan humaniora, data-data yang dianggap memiliki nilai guna, tidak hanya dikumpulkan melalui perpustakaan, tetapi juga melalui prosedur standar kajian sosiologis di lapangan, baik itu melalui wawancara, pengamatan dan riset partisipatoris. Analisis yang digunakan untuk membaca data-data tersebut menggunakan sosiologi pengetahuan, khususnya yang dirumuskan oleh Karl Mannheim (1893-1947). Fungsi utama menggunakan analisis sosiologi pengetahuan adalah segala kelebihan dalam menjelaskan pelbagai persoalan ide, gagasan, atau pengetahuan baik secara konstruktif maupun diagnostik. ${ }^{2}$

Secara sistematis, tulisan ini akan disajikan dalam enam bagian, yakni: Pertama, tentang JIMM di tengah berbagai ide kemanusiaan mutakhir; Kedua, JIMM dan historisitas ide-ide kemanusiaan di dalam Muhammadiyah; Ketiga, JIMM dan pencapaian intelektualismenya, khususnya menyangkut ide-ide kemanusiaan masa kini; Keempat, JIMM dan gagasan internasionalisasi pemikiran Islam Indonesia; Kelima, corak intelektualisme Muhammadiyah masa depan; dan yang keenam, adalah kesimpulan.

\section{JIMM di Tengah Pasar Raya Ide Kemanusiaan}

Pasca perayaan usia seabad Muhammadiyah dan Muktamar ke-27 yang dihelat di Makassar pada Agustus 2015, penyebaran, perkembangan dan pembangunan ide-ide kemanusiaan di lingkungan Persyarikatan mengalami kemajuan yang pesat. Setidaknya, ide yang begitu mencolok yang tiada pernah diperbincangkan sebelumnya adalah menyangkut internasionalisasi kiprah Muhammadiyah. Menurut Amin Abdullah, Muhammadiyah belum mengambil bagian dalam dakwah di dunia internasional. ${ }^{3} \mathrm{Hal}$ yang senada juga diungkapkan oleh Din Syamsuddin bahwa kontribusi Muhammadiyah dan sejumlah negara Muslim di bidang kompetisi peradaban dunia, masih kalah dengan pelbagai negara di Barat seperti New Zealand, Luxembourg dan Irlandia. ${ }^{4}$ Persoalan pokok yang krusial mengenai masalah di atas sebenarnya telah disinggung oleh Scheherazade S. Rehman dan Hossein Askari melalui argumentasi yang sangat brilian;

"In the post 9/11 era, there is growing interest in the complex relationship between religion, economics, finance, politics, law, and social behavior. This has

2 Karl Mannheim, Ideology and Utopia (London: Routledge \& Kegan Paul, 1976).

3 Personal interview dengan Amin Abdullah, 17 Juli 2014 di Malang.

4 Pidato Din Syamsuddin pada pembukaan forum "Tadarus Pemikiran Kaum Muda Muhammadiyah,” diselenggarakan oleh JIMM pada 17 Juli 2014 di UMM Malang. 
brought with it a disagreement on how to investigate the impact of religiosity, whether religion affects the economic, political, and social outlook of countries or whether these factors affect religiosity? In other words, should religion be viewed as a dependent or an independent variable? ...we ask what we believe to be the precursor question to such linkages, namely, do self-declared Islamic countries, as attested by membership in the OIC (Organization of Islamic Conference), embrace policies that are founded on Islamic teachings? We believe that only once this question is addressed can one begin to estimate how Islam adherence to Islam may affect economic, political and social behavior. ..." 5

Jelas bahwa strategi internasionalisasi yang dimaknai sebagai perluasan wilayah dakwah, mengandung misi yang lebih fundamental. Menurut Pradana Boy ZTF, selaku Presidium Nasional JIMM, ia mengungkapkan pentingnya gagasan Islam yang memihak kemanusiaan, namun dalam skala yang lebih global. ${ }^{6}$ Setidaknya diseminasi pelbagai etiko-religius seperti moderatisme Islam, demokrasi, pemerintahan yang baik, hak asasi manusia, keadilan sosial dan ekonomi, serta keterlibatan akan kemajuan pengetahuan, sains dan teknologi, merupakan jalan yang mampu mengatasi segala krisis kemanusiaan global seperti perang, terorisme, radikalisme-ekstremisme keagamaan dan hegemoni dominasi ekonomi, serta merebaknya kemiskinan dan ketertinggalan taraf pendidikan.

Sesungguhnya internasionalisasi yang dimaksud berlandas pada ideologi Islam yang bernuansa sosialis namun humanis. Islam yang sosialis-humanis ini, pada gilirannya tidak memandang pengelompokan dan klasifikasi politis yang tendensius, mengenai siapa saja yang menjadi korban dari segala krisis kemanusiaan global. Patron intelektual JIMM garda depan, Moeslim Abdurrahman, kerapkali membawa masalah ini pada diskusi yang penuh kejenakaan bahwa, “Tidak ada lapar yang Islam, yang Kristen, atau agama-agama yang lain. Karena lapar adalah masalah kemanusiaan yang universal." ${ }^{7}$ Karena itu, sudah saatnya Islam termanifestasikan dalam realitas sosial dan kemanusiaan yang benar-benar nyata. Islam yang secara ideal bersifat solutif harus mampu ditransformasikan agar berdampak pada perubahan sosial. Inilah yang menurut Moeslim disebut sebagai Islam transformatif. Lanjut Moeslim;

5 Scheherazade S. Rehman dan Hossein Askari, "How Islamic are Islamic Countries?," Global Economy Journal, Vol. 10, Issue 2 (2010), h. 1-37.

6 Personal interview dengan Pradana Boy ZTF, 17 Juli 2014 di Malang.

7 Moeslim Abdurrahman dalam Kuliah Umum, "Menggugat Modernitas Muhammadiyah,” yang diselenggarakan oleh Pusat Studi Islam dan Filsafat (PSIF), 13 Maret 2010, di UMM, Malang. 
"Islam Transformatif, pada dasarnya adalah sebuah impian teologis, yakni bagaimana agar makna agama bisa diperebutkan oleh mereka yang terpinggirkan, bukan dalam adu otoritas tentang siapa yang boleh menafsirkan dan tidak boleh menafsirkan makna suci, tetapi bagaimana Islam boleh menjadi ruh pembelaan bagi mereka yang sengsara tatkala mereka yang menindas dengan kekuasaannya juga menggunakan pembenaran agama yang sama."

Sesungguhnya, universalitas yang diafirmasi oleh JIMM adalah nilai-nilai teologi Islam yang menaruh perhatian terhadap perkara pokok seruan moral keberpihakan terhadap kemanusiaan. Menimbang ulang posisi marginal kaum mustadl'afin di tengah kehidupan sosial yang terus mengalami perubahan adalah sudut pandang yang menjadi ciri khas manifestasi pemikiran Muhammadiyah yang lebih kritis, yang dimainkan perannya secara lebih baik oleh para intelektual muda di lingkungan tersebut. Zuly Qodir menegaskan bahwa, “...adalah realitas yang sangat menyesakkan dada kita, tatkala kita menyaksikan betapa menderitanya para buruh migran Indonesia, - selaku para musafir di dunia modern yang serba susah (mustadl'afin) - lantas tidak menjadi bagian dari kerja pemerdekaan agama kita." Karena itu, kerja liberasi sosial agama, perlu diterjemahkan dalam agenda yang lebih serius dan menyeluruh sebagaimana yang diungkapkan Zakiyuddin Baidhawy, bahwa hal itu bisa dilakukan melalui program pembangunan "masyarakat Islam yang sebenar-benarnya (MIYS) di bumi Indonesia."10

Secara historis, bangunan ide ini sebenarnya telah dimulai sejak berdirinya Muhammadiyah oleh KH. Ahmad Dahlan. Sejarah mencatat, Dahlan merupakan pencetus tafsir keagamaan Islam yang bervisi liberasi sosial. Terma seperti "Islam yang berkemajuan"11 merupakan kunci hermeneutik yang tidak dapat dipungkiri telah menjadi warna dan karakter dalam seluruh aspek pemikiran Islam Muhammadiyah. Islam yang berkemajuan adalah mazhab yang lebih ditekankan tatkala dalam realitas sosial yang sebenarnya, umat Islam berhadapan dengan

$8 \quad$ Moeslim Abdurrahman, "Pengantar," Suara Tuhan Suara Pemerdekaan (Yogyakarta: Kanisius, 2009), h. 11.

9 Personal interview dengan Zuly Qodir pada 31 Oktober 2014, di Solo.

10 Zakiyuddin Baidhawy, "Merujuk al-Qur'an Menafsir Cita-Cita Muhammadiyah," Makalah dipresentasikan dalam "Tadarus Pemikiran Kaum Muda Muhammadiyah: Muhammadiyah dan Gerakan Sosial Baru" yang diselenggarakan oleh Universitas Muhammadiyah Malang bekerjasama dengan Jaringan Intelektual Muda Muhammadiyah, Malang 17-19 Juli 2014.

11 Amin Abdullah, "Ihsan dan Tasawwuf dalam Khazanah Pemikiran Islam (3)," Suara Muhammadiyah, Edisi No. 18 (98) (16-30 September 2013), h. 22-23; Lihat juga Amin Abdullah, "Paradigma Tajdid: Muhammadiyah sebagai Gerakan Islam Modernis-Reformis," Media Inovasi: Jurnal Ilmu dan Kemanusiaan, Edisi Khusus Muktamar Satu Abad Muhammadiyah (2010), h. 20-25. 
banyak sekali persoalan krisis kemanusiaan. Konteks sosial kolonialisme, imperialisme, feodalisme dan berkembangnya gaya hidup fatalisme akut pada masa itu, menjadikan Muhammadiyah sebagai gerbong penggerak perubahan sosial masyarakat Islam yang memihak para kaum mustadl'afin. ${ }^{12}$

Karena itu, dewasa ini, kurang tepat apabila menyebut JIMM - yang secara historis memiliki keterkaitan erat dengan visi progresif KHA. Dahlan dan Muhammadiyah awal - sebagai gerombolan "anak haram" yang mengusung ideide liberalisme keagamaan. ${ }^{13}$ Sebenarnya, dari pada liberalisme, yang menjadi dasar pijak ideologi JIMM secara umum adalah liberasi sosial. Maka, program utama JIMM bukanlah liberalisasi agama, tetapi agama untuk liberasi sosial kemanusiaan. Akan menjadi suatu hal yang terburu-buru dan pada akhirnya merupakan keputusan yang gegabah, apabila menyejajarkan JIMM dengan pemikiran Islam liberal (Islib/Islamlib) yang direpresentasikan oleh Jaringan Islam Liberal (JIL). Wacana JIL kerap mendorong terbitnya ide, pemikiran dan perilaku liberalisme Islam melalui segala upaya liberalisasi, sementara JIMM sudah melampaui upaya tersebut dan telah mencapai taraf pemikiran ulang terhadap pembangunan masyarakat madani di bumi Nusantara, yang masih terpinggirkan dalam persaingan global.

Isu-isu kemanusiaan kontemporer yang sedang dirayakan secara gegap gempita seperti pluralisme, multikulturalisme, nasionalisme kebangsaan (pribumisasi, nasionalisasi) dan juga kosmopolitanisme diterima seluruhnya oleh JIMM, namun dalam cita rasa yang khas, yang menekankan pada esensi pemikiran sosial kritis (sosialisme-humanis). Dalam benak JIMM, berbagai paham yang memberikan ruang "kebebasan" yang lebih leluasa pada keniscayaan keberbedaan (subyek, kebiasaan, tradisi, adat, agama dan kultur), harus memiliki kaitan langsung terhadap siapa saja yang termarginalisasikan secara sosial. Seseorang atau sekelompok orang yang pluralis, multikulturalis, nasionalis, pribumi dan kosmopolitanis, tiada artinya apabila acuh terhadap perkara-perkara penderitaan yang dialami oleh kaum mustadl'afin.

\footnotetext{
12 Hasnan Bachtiar, "Neo Sufisme Muhammadiyah dalam Artikulasi Teoretika," Neo-Sufisme Muhammadiyah (Malang: UMM Press, 2015).

13 Pradana Boy ZTF., M. Hilmi Faiq dan Zulfan Barron (eds.), "Dianggap Liberal , JIMM Diadili," Era Baru Gerakan Muhammadiyah (Malang: UMM Press dan al-Ma'un Institute Jakarta, 2008), h. 211-2; Lihat juga Ahmad Najib Burhani, "JIMM: Pemberontakan Generasi Muda Muhammadiyah terhadap Puritanisme dan Skripturalisme Persyarikatan,” dlm. Neng Dara Afifah (ed.), Reformasi Gerakan Keislaman Pasca Orde Baru: Upaya Merambah Dimensi Baru Islam (Jakarta: Balitbang Depag RI, 2006), h. 352-399.
} 
Kendati demikian, sebaliknya, liberasi sosial yang terinspirasi dari makna teologis suatu agama, akan menjadi gerakan radikalisme kagamaan, apabila mengabaikan pelbagai aspek penting dari kebebasan. Karena itu, Ahmad Syafii Maarif pernah menandaskan bahwa kebebasan dan pembebasan sosial harus berjalan beriringan demi mewujudkan cita-cita Islam yang luhur, yakni, “...mewujudkan masyarakat Islam yang sebenar-benarnya." ${ }^{14}$ Implikasi dari pemikiran kritis ini, membawa JIMM berdiri pada posisi yang menolak segala pemikiran keagamaan yang fundamentalis, literalis-skripturalis, revivalis, ekstrim dan radikal. Selain itu, JIMM juga melawan garis-garis pemikiran yang liberalis tanpa liberasi sosial (neo-liberalis), kapitalis (neo-kapitalis), komunis (neo-komunis), imperialis (neo-imperialis) dan kolonialis (neo-kolonialis). Sekali lagi seperti dalam ungkapan Syafii Maarif, “...kita harus kembali kepada al-Qur'an dan Sunnah, dalam pengertian, kepada nilai-nilai etis Islam yang menekankan pada keadilan, kemerdekaan, kesetaraan dan kemanusiaan, serta seluruh nilai akhlaq al-karimah." ${ }^{15}$

Artikulasi intelektual Moeslim Abdurrahman di bawah ini, bisa menjadi pertimbangan bagi kita semua,

"Bukannya bermaksud mengecilkan pembicaraan tentang, misalnya, soal hubungan antara kelompok mayoritas dan minoritas, atau pentingnya membangun perspektif Islam yang lebih infklusif berkenaan dengan iman orang lain, atau betapa dalam masyarakat patriarkhal (berorientasi pada laki-laki, ed.) ini perlu menumbuhkan kesadaran jender. Tapi yang lebih signifikan saya rasu harus kita rumuskan apakah artikulasi "perbedaan" lebih penting ketimbang "pembebasan" atau makna "pemerdekaan". Tatkala hal-hal seperti soal orang yang terkena busung lapar terjadi secara massif, soal orang yang kehilangan pekerjaan yang menambah alienasi sosial setiap hari jumlahnya semakin banyak dan tidak mungkin hal seperti ini bisa kita pahami lagi dari segi hubungan antar agama, atau dari segi perspektif wacana lintas budaya yang alami (sekedar ada fakta keragaman dan perlunya pengakuan secara politis tentang ragamnya budaya tersebut), sudah barang tentu pengakuan terhadap keragaman harus pertama-tama diletakkan di atas perjuangan keadilan sosial." 16

14 Ahmad Syafii Maarif, "Keniscayaan Kebebasan Berfikir dalam Muhammadiyah," dlm. Ajang Budiman dan Pradana Boy ZTF. (eds.), Menggugat Modernitas Muhammadiyah: Refleksi Satu Abad Perjalanan Muhammadiyah (Jakarta: Best Media dan PSIF UMM Malang, 2010), h. 132.

15 Ahmad Syafii Maarif dalam Kuliah Umum yang bertajuk "Gagasan Islah dan Tajdid Muhammadiyah," yang diselenggarakan oleh Islamic Renaissance Front (IRF) Malaysia, di Graha Pemuda Sri Hartamas, Kuala Lumpur, Malaysia, pada 21 Juni 2014.

16 Moeslim Abdurrahman, "Islam dan Keragaman Budaya," dalam Denny Mizhar dan Hasnan Bachtiar (eds.), Merajut Kebersamaan dalam Keragaman (Malang: RESIST Literacy dan Cordaid, 2010), h. 3. 


\section{JIMM dan Historisitas Ide-ide Kemanusiaan}

Pencapaian pemikiran di lingkungan JIMM tidak terbangun secara natural begitu saja. Seolah tanpa sebab sosio-politik, lantas terdapat sekelompok anak muda Muhammadiyah, yang memiliki pemikiran gemilang mengenai masa depan umat manusia. Namun, pemikiran ini memungkinkan apabila kita menganut pandangan yang esensialistik, terlebih dikuatkan dengan legitimasi tekstual teologis bahwa Nabi telah memprediksi apabila setiap seratus tahun akan lahir generasi pembaharu di lingkungan tertentu. Penulis beranggapan, keimanan tidak cukup untuk diterima begitu saja, tanpa penjelasan yang lebih sosiologis yang mampu menguraikan bagaimana suatu pemikiran terbangun di lingkungan sosial tertentu.

Istilah universalitas nilai teologi Islam dan kosmopolitanisme yang menekankan keberpihakan terhadap kaum mustadl'afin, merupakan terma kunci yang akan menjadi jembatan untuk memahami historisitas ide antara Muhammadiyah dan JIMM. Sedikit banyak memang JIMM mengambil manfaat dari pemikiran kritis Muhammadiyah, terutama teologi al-Ma'un dan manifestasinya melalui lembaga Penolong Kesengsaraan Omoem (PKO) sejak 1912 silam. Satu Abad kemudian, tatkala dihadapkan dengan kenyataan tantangan neo-liberalisme dan globalisasi, dasar pijak teologis tersebut begitu penting, dalam rangka mempertahankan idealisme Islam yang sudah semestinya berkomitmen terhadap agenda menolong siapapun yang sengsara.

Melalui sejumlah literatur yang diproduksi oleh para sejarawan sosial peneliti Muhammadiyah, organisasi ini bukan hanya institusi yang didirikan oleh $\mathrm{KH}$. Ahmad Dahlan, melainkan juga suatu wadah perjuangan yang turut memberikan sumbangsih dalam membangun kualitas intelektual dan karakter para anggotanya. Keberanian Dahlan dalam mengelaborasi pemikiran Islam (tradisionalis) dengan tren kemodernan merupakan hal yang tiada pernah dipikirkan sebelumnya saat itu. Keterlibatan di dunia politik nasional melalui gerakan Budi Oetomo, Sarikat Dagang Islam yang lalu berubah menjadi Sarikat Islam, mengajar agama di Kwekschool Het de Bible, serta pada akhirnya mendirikan pesantren dengan model dan gaya yang benar-benar berbeda dari pesantren kebanyakan. Dapat dikatakan bahwa Dahlan telah menyumbang pembaruan pemikiran Islam, tetapi kondisi sosial dengan segala tekanan, rintangan, hambatan dan perlawanan yang dihadapi, jelas merupakan sejumlah faktor penting yang mendidik para intelektual 
di lingkungan organisasi tersebut, untuk mempertahankan diri dan bahkan memenangkan kompetisi. ${ }^{17}$

Setidaknya terdapat tiga kekuatan sosial, yang menjadi musuh utama Muhammadiyah (dengan demikian, musuh utama Islam), sekaligus menjadi sejumlah alasan logis secara sosio-politik dan kultural yang mematangkan dan mendewasakan Persyarikatan. Tiga kekuatan sosial tersebut adalah kolonialisme dan imperialisme Belanda, feodalisme tradisi keraton Jawa, dan fatalisme akut sebagai ideologi popular yang beredar di kalangan masyarakat Yogyakarta saat itu. Dahlan tentu menerjemahkan doktrin agama sesuai dengan kondisi sosial masyarakat setempat. Karena itu, surat dan ayat yang paling relevan untuk dielaborasi, dijadikan inspirasi gerakan dan diterapkan adalah al-Ma'un. ${ }^{18}$ Dalam surat ini terdapat kalimat penutup yang bermakna bahwa kita harus memberikan manfaat terhadap sesama.

Dalam sebagian wacana yang beredar mengenai pemikiran Dahlan, kerap disinggung persoalan kembali kepada al-Qur'an dan Sunnah. Jelas, hal itu melampaui sekedar seruan untuk mengamini skripturalisme-tekstualis. Istilah "melampaui" bermakna pembebasan sosial. Karena itu, al-ruju' ila al-Qur'an wa al-Sunnah hanya strategi yang memberantas segala unsur kultural yang membelenggu. Jelas bahwa hal itu berimplikasi pada segala penjajahan struktural, yang juga turut teratasi. Misalnya, ketika beredar wacana Islam alternatif yang mendorong kepada pemberantasan Takhayul, Bid'ah dan Churafat (TBC), itu merupakan bentuk pertarungan diskursus melawan wacana dominan yang beredar di tengah masyarakat. Dorongan untuk memberantas TBC sama sekali bukan untuk menonjolkan puritanitas Muhammadiyah - yang belakangan tereduksi maknanya menjadi fundamentalisme atau konservatisme keagamaan - akan tetapi sebagai strategi kreatif, dalam rangka liberasi sosial. Sungguh sangat disayangkan apabila ideologi keagamaan tradisional yang syarat dengan TBC justru membelenggu kemerdekaan umat, terutama mereka yang miskin dan tiada berpunya. Demikianlah, yang digugat oleh Muhammadiyah bukan sekedar ajaran yang salah dan sesat, tetapi juga perilaku pemilik otoritas keagamaan dan struktur kuasa yang menindas. ${ }^{19}$

17 Alfian, Islamic Modernism in Indonesian Politics: The Muhammadijah Movement during the Dutch Colonial Period (1912-1942) (Ph.D. Thesis, The University of Wisconsin-Madison, 1969).

18 Zakiyuddin Baidhawy, Teologi Neo al-Maun: Manifesto Islam Menghadapi Globalisasi Abad 21 (Yogyakarta: Civil Islamic Institute, 2009).

19 Kuntowijoyo, "Pengantar: Jalan Baru Muhammadiyah,” dlm. Abdul Munir Mulkhan, Islam Murni dalam Masyarakat Petani (Yogyakarta: Bentang, 2000). 
Di samping itu, ketika hendak menolong kesengsaraan umum, Dahlan secara terbuka dan tanpa kekhawatiran sedikitpun, melibatkan orang-orang Belanda, baik yang berprofesi sebagai dokter maupun para dermawan yang bersedia menjadi donatur Persyarikatan. Melalui tuturan Abdul Munir Mulkhan dijelaskan bahwa, "...terdapat anggota istimewa Muhammadiyah, yang diterima sebagai bagian dari Muhammadiyah, walaupun non-Muslim dan tidak berasal dari Indonesia. Mereka memiliki hak untuk bersuara dan mengusulkan pemikirannya di dalam Kongres Muhammadiyah, walau tidak memiliki hak untuk memilih dan/atau terpilih sebagai bagian dari kepemimpinan struktural organisasi." ${ }^{20}$ Inilah yang dimaksud dengan universalitas nilai teologi Islam dan kosmopolitanisme yang sudah sejak lama ada di dalam sejarah berMuhammadiyah. Dalam konteks ini, ideologi sosialisme-humanistik yang terinspirasi dari nilai-nilai teologis Islam, termanifestasikan dalam gerakan keagamaan yang tampak puritanistik, namun kosmopolitan. Syafii Maarif mengisahkan bahwa, lembaga $\mathrm{PKO}$ merupakan representasi dari kosmopolitanisme Muhammadiyah, yang mengafirmasi sosialisme-humanistik Islam. Karena yang ditolong bukan hanya umat Islam, tetapi "Kesengsaraan Omoem”, walaupun, secara historis dimulai dari Karesidenan Yogyakarta. ${ }^{21}$

Dalam rangka mengistilahkan semua itu, Dahlan menggunakan istilah "Islam berkemajuan”. Islam berkemajuan itulah yang menjadi penerang jiwa bagi para intelektual muda Muhammadiyah hingga saat ini. Sifat kosmopolitanistik Muhammadiyah yang menjadikan nilai-nilai moralitas tersebut masih relevan sampai sekarang. Pasalnya, ketika umat tidak lagi berhadapan dengan zaman yang penuh imperialisme dan kolonialisme, serta tidak berhadapan dengan feodalisme Jawa, maka terdapat penindasan dalam bentuk lain yang harus diselesaikan. Menguatnya arus neo-liberalisme dan globalisasi, negara-negara dunia ketiga seperti Indonesia, merupakan sasaran ekspansi pasar dan korban dari perdagangan bebas atau kapitalisme global. Pada akhirnya, wabah konsumerisme dan kebudayaan popular merebak luas ke berbagai negara miskin dan negara berkembang. Moda produksi, investasi dan ekonomi, menjadi kekuatan pengendali yang tak terkalahkan. Memberikan dampak hebat pada kehidupan seluruh umat manusia di pelbagai belahan dunia. Kekuatan struktural ekonomi yang berjalanan beriringan dengan kompleksitas sosio-kultural dan politik, menumbuh-suburkan krisis kemanusiaan yang luar biasa.

\footnotetext{
20 Personal interview dengan Abdul Munir Mulkhan, 7 Juni 2015 di Malang.

21 Ahmad Syafii Maarif di dalam forum IRF.
} 
Di tengah gempuran model penjajahan dan penindasan baru tersebut, Muhammadiyah telah berusaha keras menjawab segala tantangan zaman. Namun, Moeslim Abdurrahman, mantan Ketua Pimpinan Pusat Muhammadiyah di bidang Pemberdayaan Buruh, Petani dan Nelayan memikirkan betapa pentingnya kaderisasi yang juga "berkemajuan", sehingga tidak gagal paham tatkala menghadapi irama permainan neo-imperialisme dan neo-kolonialisme dewasa ini. Dengan kata lain, perlu kiranya mempersiapkan kekuatan masa depan yang tangguh, yang akan memenangkan pertarungan di kancah konstalasi peradaban global. Akhirnya, didirikanlah JIMM sebagai wadah perkumpulan kultural para intelektual muda Muhammadiyah. Anak-anak muda yang tersebar di pelbagai perguruan tinggi di Indonesia, didorong untuk menggenapkan studi akademiknya, terutama ke berbagai universitas terkemuka di dunia agar memiliki kecakapan intelektual yang unggul, namun tetap di bawah naungan ideologi Muhammadiyah. Moeslim menegaskan,

"Muhammadiyah lima atau sepuluh tahun yang akan datang akan sangat berbeda dengan Muhammadiyah yang sekarang ini. Anak-anak muda ini adalah satu generasi yang memiliki dinamikanya sendiri tatkala mereka bersentuhan dengan gelombang globalisasi, gelombang pemikiran dan sejenisnya. Oleh karena itu, di tangan anak-anak muda inilah, Muhammadiyah akan benar-benar menjadi imajinasi intelektual." 22

Tidak dapat dipungkiri bahwa sesungguhnya Muhammadiyah juga sedikit banyak terdampak oleh neo-liberalisme dan globalisasi. Penetrasi penjajahan di pelbagai bidang di negara-negara dunia ketiga, termasuk beberapa negara di Timur Tengah selama bertahun-tahun lamanya, menyisakan residu ingatan traumatik pasca kolonialisme. Menurut Fazlur Rahman, tidak heran apabila kemudian atas sebab sosio-politik dan kompleksitas kultural melahirkan revivalisme, fundamentalisme dan konservatisme keagamaan. ${ }^{23}$ Dari berbagai hal tersebut, mengarah kepada ekstremisme, radikalisme dan terorisme. Semacam terdapat pengerasan sikap keberagamaan yang tidak bisa terbendung lagi. Muhammadiyah sendiri harus bekerja ekstra dalam melindungi ideologi umat Islam, khususnya warga Muhammadiyah. Para anggota dan simpatisan, bahkan para kader Persyarikatan yang tidak cukup militan dalam ber-Muhammadiyah,

22 Moeslim Abdurrahman, "Epilog," Islam sebagai Kritik Sosial (Jakarta: Erlangga, 2003), h. 168-205. Lihat juga Moeslim Abdurrahman, "Munculnya Kesadaran Kritis Ber-Muhammadiyah: Sebuah Pengantar," dlm. Pradana Boy ZTF dan M. Hilmi Faiq (eds.), Kembali ke al-Qur'an Menafsir Makna Zaman: Suara-suara Kaum Muda Muhammadiyah (Malang: UMM Press, 2004), h. vii-xviii.

23 Fazlur Rahman, Revival and Reform in Islam: A Study on Islamic Fundamentalism (Oxford: Oneworld Publications, 2009). 
justru lebih tertarik dan terlibat dalam aktivitas gerakan Islam yang radikal atau bahkan terorisme. Lanjut Moeslim, dengan adanya JIMM juga dimaksudkan untuk memproduksi para petarung intelektual yang siap memenangkan wacana "Islam berkemajuan" di ruang publik, yang selama ini didominasi oleh wacana konservatisme dan radikalisme. Dengan kata lain, JIMM merupakan ikhtiar intelektual yang hendak mengembalikan kekuatan intelektual para kader Muhammadiyah, menuju khittah pemikiran KH. Ahmad Dahlan yang sangat progresif.

Dalam bahasa yang penuh harap, Moeslim pernah menceritakan suasana hatinya, terutama mengenai masa depan Muhammadiyah,

“...potensi-potensi intelektual yang mulai tumbuh di kalangan anak-anak muda Muhammadiyah, harus direspon dengan baik dan bahkan diberikan media yang selayaknya. Saya terkejut mendapati kenyataan bahwa belakangan semakin banyak saja jumlah anak-anak muda Muhammadiyah yang produktif dan berpikiran kontemporer, dalam arti selalu mengikuti arus perkembangan baru dalam dunia pemikiran yang tidak kalah dengan yang lain. Anak-anak muda seperti ini, ternyata berserak di beberapa tempat, seperti di Jogja, Malang, Surabaya, Jakarta, Surakarta, dll. Saya kira anak-anak muda ini tidak dilahirkan oleh Muhammadiyah, tapi mereka lebih banyak lahir karena keberaniannya untuk keluar dari tempatnya masing-masing, dan ini adalah sebuah fenomena yang amat menggembirakan." ${ }^{24}$

\section{Pencapaian Intelektualisme JIMM}

Tidak ada perbedaan signifikan antara ide-ide Muhammadiyah dengan JIMM. Hanya saja, berbagai gagasan di lingkaran komunitas intelektual anakanak muda Muhammadiyah ini, mereformulasi pemikiran kritis-transformatif Muhammadiyah. Mereka beranggapan, harus menemukan kunci hermeneutik dalam pemikiran dan filsafat yang relevan dengan tantangan zaman. ${ }^{25}$ Meski nilai-nilai etis Islam bersifat universal, namun konteks sosio-historis yang ada begitu berbeda. Tampaknya, JIMM memiliki kesadaran filsafat kebudayaan dan sejarah, karena itu mereka menyadari pentingnya kontekstualisasi ajaran Islam, sehingga bersifat transformatif bagi masa depan kemanusiaan.

\footnotetext{
24 Moeslim Abdurrahman, "Munculnya Kesadaran Kritis Ber-Muhammadiyah: Sebuah Pengantar," h. viii-ix.

25 Moeslim Abdurrahman, "Tafsir atas Wahyu: Mengedepankan Transformasi, Bukan Reformasi," Suara Tuhan, Suara Pemerdekaan (Yogyakarta: Kanisius, 2009), h. 168-184.
} 
Istilah "Islam berkemajuan" telah diterjemahkan sebagai "Islam progresif". Lalu, akal dan hati suci diterjemahkan dalam kualitas operasional rasio sebagai pemikiran liberal-liberatif/transformatif". Sementara itu, terma lainnya seperti teologi al-Ma'un dianggap sebagai teologi pembebasan Islam-Muhammadiyah dan istilah "orang-orang miskin, kaum papa dan terpinggirkan (mustadl'afin)" diterjemahkan sebagai kelompok "neo-mustadl'afin". sejumlah perubahan istilah ini bukan tanpa makna. Justru melalui berbagai kunci hermeneutik itu merupakan hasil dari kerja keras para intelektual muda terhadap konteks kehidupan masa kini, yang dielaborasikan dengan nilai-nilai etis al-Qur'an dan al-Sunnah, sebagaimana yang telah ditekankan semenjak didirikannya Muhammadiyah. Dengan demikian, sebenarnya mazhab pemikiran keagamaan JIMM dan Muhammadiyah adalah mengafirmasi kontekstualisasi etico-moralis Islam yang begitu luhur, sesuai dengan struktur dan sistem sosial, ekonomi, politik, kebudayaan, psikologi sosial dan seterusnya.

Logika kontekstualisasi ini akan sangat mudah apabila meminjam dari pemikiran Tariq Ramadan, seorang Profesor Studi Islam Kontemporer dari Universitas Oxford, Inggris. ${ }^{26}$ Menurutnya, masyarakat memiliki kewajiban untuk mengikuti segala tuntunan agama. Hanya saja, tatkala hendak memahami nilainilai etis di balik segala tuntunan agama, terdapat jarak dan kompleksitas pelbagai bidang kehidupan, sehingga tidak jarang menjadikan hal ini sebagai tantangan utama yang harus dipecahkan pertama kali. Jarak itu adalah makna, interpretasi, kebahasaan, tradisi, adat, kebiasaan, kebudayaan, sosial, politik, geografi dan yang terjauh adalah sejarah. Antara Muslim di zaman sekarang dengan praktik dan kehidupan keagamaan Nabi Muhammad, terentang berbagai jarak tersebut, sehingga setiap Muslim harus bekerja ekstra tanpa kenal lelah untuk menemukan kebenaran hakiki dan kebajikan universal dalam setiap ajaran agama Islam.

Lanjutnya, setidaknya terdapat konteks, ketika wahyu diturunkan. Wahyu ini turun dalam rangka menjawab berbagai persoalan saat itu, melalui perantara malaikat Jibril kepada Rasulullah Saw. Dengan demikian, dalam suatu bagian dari rangkaian episode pewahyuan Islam, terdapat hubungan dialektis antara teks (kitab suci al-Qur'an, dan juga al-Sunnah) dengan konteks kehidupan sosial kemanusiaan pada saat itu. Di balik dialektika antara teks dan konteks tersebut,

26 Tariq Ramadan, Western Muslims and the Future of Islam (New York: Oxford University Press, 2004); Tariq Ramadan, Islam, the West and the Challenges of Modernity (Leicester, UK: The Islamic Foundation, 2001). 
senantiasa terdapat tujuan ilahiah (maqâshid). Di balik setiap tujuan, mengandung nilai moral, moral, serta kebajikan dan hikmah dari setiap persoalan kehidupan. Inilah yang dimaksud dengan pesan global Islam.

Sangat sukar kiranya, setiap Muslim yang mencoba memahami dengan sungguh-sungguh pesan global Islam, tanpa menelusuri kompleksitas dialektika teks dan konteks dalam setiap rangkaian episode pewahyuan Islam. Karena itu, pemahaman terhadap sejarah Islam awal, mutlak diperlukan. Tidak hanya itu, kompleksitas pelbagai jarak yang disinggung sebelumnya, juga mestinya dikuasai dengan baik, untuk memahami seluruh muatan material dalam lembaran sejarah Islam awal. Kompleksitas ini benar-benar harus diarungi, karena akan membawa kepada pemahaman yang lebih komprehensif, ketimbang hanya menduga-duga makna kitab suci melalui sudut pandang filsafat kebahasaan semata. Memaksakan diri untuk menggunakan kecakapan kebahasaan semata, akan menjerumuskan ke dalam jurang skripturalisme-tekstualis yang menganga lebar. Buah yang tumbuh dari pohon represi intelektual, hanyalah ketidaktahuan, ketidakpahaman, kedangkalan-pengertian dan stagnasi, serta kegemaran untuk cenderung berpikir taklid secara membabi-buta tanpa alasan yang jelas.

Tidak selesai dengan ikhtiar penemuan nilai, tujuan dan pesan global, karena setiap Muslim harus memahami situasi sosial kemanusiaan kekinian yang juga tidak kalah kompleksnya. Setidaknya, berbagai dimensi sosio-politik dan kebudayaan harus dipahami secara lebih sempurna, dalam rangka mengimplementasikan nilai, tujuan dan pesan global yang telah diraih. Tanpa mereduksi sedikitpun - terlebih korupsi makna - terhadap segala dimensi nilai etis al-Qur'an dan al-Sunnah, proses kontekstualisasi dilakukan dengan cara-cara yang benar dan tidak menimbulkan efek tertentu yang justru bersifat destruktif. Dengan demikian, terdapat tiga langkah penting dalam rangka kontekstualisasi etico-moralis Islam sebagai spirit ber-Muhammadiyah, yakni: dialektika teks dan konteks historis, penemuan pesan global dan implementasi/kontekstualisasi.

Di dalam buku yang bertajuk "Kembali ke al-Qur'an, Menafsir Makna Zaman,” Moeslim Abdurrahman mengajukan strategi kontekstualisasi yang begitu penting bagi JIMM. Strategi ini ia sebut sebagai "Tiga Pilar JIMM", yakni antara lain: hermeneutika, ilmu sosial kritis dan gerakan sosial baru. Pertama, melalui hermenutika sebagai alat analisis, diharapkan akan terjadi reproduksi makna atas wahyu ilahi yang termanifestasikan dalam al-Qur'an, “...sehingga makna- 
makna zaman baru kemudian bisa dikontrol dengan refleksi-refleksi Qur'ani;"27 Kedua, melalui ilmu sosial kritis sebagai alat analisis, diharapkan akan mampu mendiagnosa adanya hegemoni kekuasaan yang menindas yang terdiseminasi ke pelbagai bidang, dan membangun kekuatan counter-hegemony, “...yang menekankan pada penyadaran kaum tertindas dan pentingnya membangun perspektif teologi pembebasan;" ${ }^{28}$ sementara itu yang ketiga, gerakan sosial baru merupakan cara berteologi yang berbeda dengan model teologi formal. Teologi dalam konteks ini adalah "...sebuah gerakan, sehingga teologi merupakan kerja pedagogis kemanusiaan yang bisa berwatak pembebasan.” Di samping itu, agar lebih sempurna, teologi ini juga harus ditunjang empat hal penting yang "...dapat merubah tingkat kesadaran intelektual... yaitu: capital on the move, media on the move, people on the move, dan gagasan-gagasan revolusioner," dalam rangka mengarungi gelombang besar globalisasi dewasa ini. ${ }^{29}$

Sekali lagi, inilah yang mungkin akan membedakan corak pemikiran JIL dengan JIMM, yakni adanya tendensi liberasi sosial yang tidak dimiliki oleh JIL. Pradana Boy ZTF., mengonfirmasi perbedaan ini dengan mengajukan klaim bahwa, "JIMM berorientasi pada pembangunan intelektualisme di lingkungan anak-anak muda Muhammadiyah yang memihak keadilan sosial dan kemanusiaan, terutama bagi mereka kaum mustadl'afin." ${ }^{30}$ Lanjutnya, pada tahun 2005 di mana saat kenaikan BBM menyentuh harga Rp4.500 dari Rp1.500, kelompok Islam liberal malah mendukung segala kebijakan pemilik kekuasaan yang tidak prorakyat tersebut. Tentu saja dukungan ini menunjukkan bahwa betapa liberalisme berbeda dengan liberalisme yang berorientasi liberasi sosial (liberative action).

Menurut paradigma berpikir JIMM, Islam bukan sekedar memberikan ruang bagi kemerdekaan berpikir, tetapi juga bertindak liberatif di hadapan kehidupan sosial kemanusiaan yang membelenggu. Dalam konteks mendiagnosa masalah perekonomian umat misalnya, yang pada zaman dahulu diselesaikan melalui mekanisme zakat, maka saat ini terdapat strategi yang berbeda, walau dengan nilai yang sama: keadilan. Apabila zakat merupakan sistem penarikan pajak yang

27 Moeslim Abdurrahman, "Munculnya Kesadaran Kritis Ber-Muhammadiyah: Sebuah Pengantar," h. x.

28 Moeslim Abdurrahman, "Munculnya Kesadaran Kritis Ber-Muhammadiyah,” h. xi.

29 Moeslim Abdurrahman, h. xii.

30 Personal interview dengan Pradana Boy ZTF pada Kamis, 3 September 2015. Bandingkan dengan pernyataannya mengenai hal ini dalam tulisan yang bertajuk "JIMM: Sebuah 'Teks' Multitafsir," Era Baru Gerakan Muhammadiyah (Malang: UMM Press dan al-Ma'un Institute Jakarta, 2008), h. 47-51. 
sederhana (fiskal), yang kemudian didistribusikan secara adil kepada seluruh rakyat, maka di hadapan kehidupan sosial yang lebih kompleks di era negara bangsa dan globalisasi ini, hal itu tidak bisa digunakan lagi. Tutur Moeslim, "Betapapun kita kaya raya dan hendak menzakatkan seluruh kekayaan kita, maka sekali-kali tidak akan mungkin mengentaskan kemiskinan di negeri ini yang laju perkembangannya jauh lebih pesat dari sistem zakat kita." ${ }^{11}$ Pada intinya, zakat merupakan tindakan empati dan welas asih dari para si empunya kekayaan finansial, terhadap mereka yang miskin dan tiada berpunya. Maksudnya jelas, bukan hanya agar orang-orang miskin memiliki sejumlah kekuatan finansial, tetapi juga kemampuan untuk membangun sustainabilitas dan kesejahteraan mereka pula. Karena itu secara etis, kitab suci menyinggung “...agar supaya kapital itu tidak hanya dikuasai, dihegemoni dan didominasi oleh para kaum kapitalis belaka (kayla yakûna dullatan baina al-aghniyâ'i minkum).

Berjalan beriringan dengan alur pemikiran di atas, sebenarnya terdapat penjelasan yang jernih bahwa, bukanlah sistem zakat yang operasionil yang mesti dikedepankan. Karena hal itu, hanya akan menjadi institusi yang berderajat sama dengan perusahaan pendulang profit dan akumulasi kapital lainnya yang abai terhadap kesengsaraan umum umat manusia dewasa ini. Artinya, nilai-nilai keadilan dalam zakat, harus dikontekstualisasikan dalam perilaku ekonomi yang lebih luas dan menyeluruh - baik yang berlaku dalam tataran bisnis mikro maupun makro. Advokasi sosial, ekonomi dan politik harus menjadi semacam jihad fi sabilillah yang utama, demi mengupayakan keadilan bagi kelompok termarginalkan dalam kontes kehidupan global yang dikendalikan oleh sistem ekonomi yang neoliberalistik.

Karena itu, misalnya, istilah musafir dalam al-Qur'an yang menjadi sosok sasaran zakat, tidak boleh dipahami sebagai orang-orang yang bepergian menurut kategori kitab-kitab fiqih atau tafsir masa lalu, tetapi mereka yang benar-benar menderita oleh karena globalisasi dan neoliberalisme. Musafir sebagai bagian dari neo-mustadl'afin misalnya, adalah mereka para buruh migran (Tenaga Kerja Wanita atau Tenaga Kerja Indonesia) yang membanting tulang ke negeri-negeri seberang demi mempertahankan hidup, sementara hak-hak asasi mereka rentan untuk dilanggar. Baginya, bukan hanya raga yang jauh dari keluarga dan sanak

31 Moeslim Abdurrahman dalam Kuliah Umum di Padepokan HW Malang pada 13 Maret 2010. Lihat transkrip kuliahnya dalam https://kataitukata.wordpress.com/2012/07/06/ kuliah-dr-moeslimabdurrahman/ (diakses pada 7 Juni 2015). 
saudara, tetapi juga keamanan, harkat dan martabat, serta bahkan kehidupan mereka sendiri (nyawa) yang sedikit sekali mendapatkan perlindungan oleh karena sistem perbudakan kontemporer.

\section{JIMM dan Gagasan Internasionalisasi}

Pada mulanya, di pertengahan tahun 2012, akan dihelat kolokium pemikiran JIMM di Yogyakarta. Namun, karena kondisi kesehatan Dr. Moeslim Abdurrahman selaku mentor intelektual JIMM yang tidak memungkinkan, maka program ini ditunda, sembari menunggu kesehatannya membaik. Tidak berselang lama setelah itu, muncullah kabar duka bahwa mentor intelektual JIMM tersebut telah wafat di Jakarta pada Jum'at, 6 Juli 2012. Hal ini tentu membuat seluruh intelektual yang tergabung dalam wadah kultural JIMM menyimpan duka yang mendalam. Persiapan yang matang dan bahkan, rencananya akan mendatangkan sejumlah sarjana asing peneliti JIMM, harus benar-benar ditunda dalam rangka berbela sungkawa atas kondisi ini. Akhirnya dua tahun kemudian, pada 17-19 Juli 2014 program ini baru terealisasi dengan nama “Tadarus Pemikiran Kaum Muda Muhammadiyah” yang diselenggarakan di Universitas Muhammadiyah Malang.

Maksud kedatangan para peneliti asing tersebut sesungguhnya hendak menyatakan bahwa, JIMM telah menjadi perhatian intelektual akademik di lingkungan internasional, terutama di berbagai universitas terkemuka di dunia. Ketika wacana Islam liberal yang diusung JIL mulai meredup, - mungkin dianggap kontraproduktif dengan misi liberalisasi pemikiran Islam di Indonesia, karena justru menumbuh-suburkan konservatisme di kalangan umat Islam lainnya $^{32}$ - JIMM sebagai wacana merupakan alternatif yang bisa menjadi representasi corak pemikiran Islam Indonesia di masa mendatang. Setidaknya dua sarjana terkemuka berkomentar atas adanya "Tadarus JIMM" tersebut, yakni: Mitsuo Nakamura dan Azhar Ibrahim Alwee. Walau fisiknya tidak hadir dalam acara tersebut karena alasan kesehatan, Nakamura menyampaikan bahwa

32 Azhar Ibrahim, "Against 'Islam Liberal': A Reactionary Discourse of Religious Conservatives and the Response of Progressives," Contemporary Islamic Discourse in the Malay-Indonesian World: Critical Perspectives (Malaysia: SIRD, 2013), h. 241; Lihat juga Mohamad Ishsan Alief, "Political Islam and Democracy: A Closer Look at the Liberal Muslims," Wilson Center: Asia Program Special Report, No. 110, 2003, h. 14; Lily Zakiyah Munir, "Agendas for 'Liberal Islam': Contending Radicalism, Promoting Interfaith Dialogue and Pursuing the Rights of the Poor," ICIP Journal, Vol. 2, No. 3, 2005, h. 7. 
ia begitu gembira karena masa depan wacana Muhammadiyah dan Islam Indonesia akan berkibar di tangan para intelektual tangguh di lingkungan JIMM. Nakamura melanjutkan ungkapan perasaannya, "Let me congratulate you for initiating a gathering of young scholars-activists in and around Muhammadiyah at UMM. Semoga sukses dan selamat berpuasa! Salam hangat, Mitsuo Nakamura." 33 Sementara itu Azhar Ibrahim yang hadir dalam acara tersebut mengungkapkan bahwa,

"Pada diri JIMM, saya melihat intelektualisme sebagai wujud dari tanggung jawab sosial, bukan sebagai jubah narsistik. Mereka tidak ingin menjadi selebriti intelektual...Apapun perspektif yang diangkat oleh aktivis JIMM, dan bagaimanapun model pemikirannya, tujuan utamanya selalu sama, yaitu memihak kaum yang terpinggirkan secara sosial. Bentuk pemihakannya juga tidak bersifat karitatif, misalnya dengan memberi secara material, tapi lebih pada penyadaran, pencerahan dan pemberdayaan." 34

Apa yang terjadi di ruang akademik internasional jelas tidak boleh didiamkan begitu saja. Dengan kata lain, JIMM harus menjadi gayung bersambut yang siap merayakan program internasionalisasi wacana pemikiran Islam Indonesia (yang memihak) di dunia global. Terlebih dalam situasi di mana sebagian negaranegara Muslim sedang mengalami proses demokratisasi yang berharga mahal karena harus diiringi dengan krisis kemanusiaan seperti konflik, karut marut pemerintahan, kemiskinan dan seterusnya - maka promosi Islam Indonesia dengan segala kelebihannya menjadi hal yang penting. ${ }^{35}$ Perkara ini jelas bukanlah aji mumpung, karena dalam konstalasi wacana pemikiran di dunia global, harus diselesaikan di ruang global pula. Misalnya, oleh karena sebab-musabab penjajahan baru oleh gelombang neoliberalisme, peradaban di negara-negara miskin, negara dunia ketiga, serta negara yang menjadi sasaran ekspansi pasar menjadi hancur luluh lantah.

Internasionalisasi pemikiran Islam Indonesia ini, bagi JIMM juga merupakan agenda "moderasi" atas pengerasan sikap beragama, terutama di lingkungan umat Islam sendiri. ${ }^{36}$ Memang pengerasan sikap ini merupakan fenomena

\footnotetext{
33 Lihat komentar Nakamura di http://www.umm.ac.id/id/umm-news-4188-ikhtiar-intelektual-ummjimm-dipuji-dua-peneliti-asing.html (diakses pada 8 Juni 2015).

34 Personal interview dengan Azhar Ibrahim Alwee pada 1 Desember 2014 di Malang dan 26 Februari 2015 di Singapura.

35 Dawam Rahardjo dalam Seri Kuliah Umum PSIF yang bertajuk "Politik Dunia Islam yang Bergejolak," pada 24 April 2015, di Universitas Muhammadiyah Malang.

36 Personal interview dengan Pradana Boy ZTF., pada 7 Juni 2015 di Batu, Malang.
} 
kontemporer yang disebabkan oleh pelbagai hal, terutama arus globalisasi dan neoliberalisme yang tak terkendali. Di pelbagai media sosial misalnya, caci maki, pengecaman, ujaran kebencian, provokasi kekerasan, teror, pengafiran dan seterusnya, menjadi konsumsi yang dominan ketimbang wacana pemikiran Islam yang mengedepankan keramahan, perdamaian, luhurnya budi, toleransi dan berkeadaban. Sangat tidak mungkin perlawanan terhadap segala penjajahan global, dilakukan melalui pengerasan sikap yang tidak disadari tersebut. Akan menjadi hal yang lebih memilukan, apabila pengerasan sikap beragama tersebut dimanfaatkan oleh sebagian pihak secara politis, dalam rangka memenuhi kepentingan sendiri atau kelompoknya sendiri. ${ }^{37}$ Menyinggung masalah ini, Bambang Setiaji, Rektor Universitas Muhammadiyah Surakarta menandaskan bahwa,

"Dalam menghadapi kemelut di Timur Tengah, Muhammadiyah bisa berandil dalam mencegah masuknya paham kekerasan ke dalam negeri. Sebagai gerakan Islam modern yang memiliki banyak sekolah, Muhammadiyah tidak mengajarkan kekerasan sebagai penyelesaian masalah." 38

Isi dan substansi "moderasi" atas pengerasan sikap beragama ini, tidak hanya menyinggung persoalan toleransi dan perdamaian semata. Tetapi juga kerjasama di antara pelbagai umat beragama, dalam rangka menebarkan kebajikan universal, termasuk advokasi wacana tentang keadilan sosial dan kemanusiaan..$^{39}$ Karena itu, sejumlah wacana mengenai "Islam kontekstual", "Islam Indonesia", "Islam Nusantara”, "Islam berkemajuan", "Islam yang memihak", "Islam transformatif", "Islam progresif" dan seterusnya, diupayakan agar menjadi kekuatan alternatif yang berhadapan dengan wacana dominan yang beredar di dunia internasional. Konsep negara/kota Islami seperti yang disinggung oleh Scheherazade S. Rehman dan Hossein Askari di awal tulisan ini, hanya menjadi hal yang absurd menurut sudut pandang kosmopolitanisme, selama beberapa negara dunia pertama menjajah negara dunia ketiga dan miskin. Tidak dapat dipungkiri bahwa, situasi dan kondisi perekonomian makro di dunia internasional sangat memengaruhi negara-negara berkembang dan tentu saja, negara-negara miskin.

37 Mari kita cermati diagnosa Moeslim Abdurrahman dalam "Krisis Sosial, Krisis Politik, dan Krisis Bangsa Majemuk," Suara Tuhan, Suara Pemerdekaan (Yogyakarta: Kanisius, 2009), h. 17-44.

38 Bambang Setiaji, "Mewujudkan Peta Jalan Internasionalisasi Muhammadiyah," Jawa Pos 14 April 2015.

39 Sukidi Mulyadi, "Menjadi Muslim Pluralis: Pergulatan Mencari Kebenaran dan Tuhan," Muhammadiyah Progressif: Manifesto Pemikiran Kaum Muda (Jakarta: JIMM dan LESFI, 2007), h. 426. 
Dalam konteks di atas, komentar Ahmad Najib Burhani sangatlah tepat untuk menggambarkan mengenai internasionalisasi yang dikehendaki,

“...dalam dunia yang global ini semua umat manusia harus melakukan interaksi dan bekerjasama yang lebih baik demi tujuan kemanusiaan. Tujuan dari internasionalisasi bukanlah untuk melakukan hegemoni ataupun membuat perubahan dunia secara drastis, tapi melakukan kerjasama untuk menciptakan dunia yang damai." ${ }^{40}$

Di samping itu, contoh detil seperti yang disampaikan oleh Zuly Qodir, merupakan contoh terbaik, yang secara tepat membidik kompleksitas wacana keberpihakan Islam progresif, yang berhadapan dengan neoliberalisme dan globalisasi. ${ }^{41}$ Ketika umat Islam bekerja keras mempromosikan pentingnya Islam yang memihak, melalui berbagai program filantropisme Islam misalnya, mereka berhadapan secara sengit dengan arus kebudayaan popular yang merebak pesat. Bahkan, pelbagai program Islam konvensional seperti penawaran menyumbangkan hewan kurban, donasi untuk pesantren dan rumah yatim piatu, dan lain-lain bersaing dengan penawaran bisnis multi level marketing, bisnis property di luar negari, barang-barang impor dan seterusnya, hingga diselingi oleh bisnis klenik dan khurafat, prostitusi dan perjudian. Karena itu, tidak cukup kiranya apabila melawan pelbagai tantangan kekinian hanya melalui dakwah dari khutbah ke khutbah, atau dari pengajian ke pengajian. Internet sebagai media global misalnya, menjadi wilayah garapan dakwah yang juga harus diprioritaskan. Tidak hanya bagi warga Muhammadiyah, umat Islam Indonesia dan seluruh umat yang tersebar di wilayah Nusantara, tetapi juga dunia internasional, yang disampaikan melalui komunikasi (bahasa) yang dimengerti oleh dunia global pula.

Karena pentingnya program internasionalisasi, salah seorang mentor intelektual JIMM lainnya, Amin Abdullah menandaskan,

"Jika Muhammadiyah dan umat Islam Indonesia yakin bahwa mereka memang mempunyai sesuatu yang dapat ditawarkan dan dibagikan kepada publik di pentas dunia global (has something to offer to the world), maka sudah tiba saatnya sekarang Muhammadiyah khususnya generasi mudanya merenung tentang

40 Ahmad Najib Burhani, "Internasionalisasi Muhammadiyah," Tanwir: Majalah Kauman, Ikatan Mahasiswa Muhammadiyah, Edisi Maret-April 2015, h. 46. Bandingkan dengan pernyataan Najib Burhani lainnya dalam "Internasionalisasi Gerakan Muhammadiyah," Suara Muhammadiyah, 11/ 100, 1-15 Juni 2015.

41 Zuly Qodir, "Muhammadiyah dan Gerakan Islam Non-Mainstream," paper dipresentasikan dalam "Tadarus Pemikiran Kaum Muda Muhammadiyah," diselenggarakan oleh JIMM pada 17 Juli 2014 di UMM Malang. 
apa yang dapat ditawarkan dan apa yang hendak kita kerjakan pada abad ke 21 ini, khususnya ketika Muhammadiyah telah melewati 100 tahun usianya (centennial anniversary). Peluangnya tetap ada, namun tantangannya juga jelas di hadapan kita bersama. Modal sosial, kultural dan ekonomi Indonesia bukannya tidak punya."

Secara lebih lanjut, Amin Abdullah sendiri menawarkan tiga strategi utama dalam rangka mempromosikan pemikiran JIMM, Muhammadiyah dan Islam Indonesia, yakni: penerjemahan besar-besaran, mendirikan universitas berkualitas internasional dan revolusi mental menuju pengafirmasian terhadap wawasan kosmopolitanisme. pertama, melalui penerjemahan karya-karya kelompok intelektual Muslim dalam bahasa Arab dan Inggris. Apabila memungkinkan, juga dalam bahasa-bahasa Eropa seperti Jerman, Perancis, Belanda dan Spanyol. Ia berkomentar,

“...untuk memenuhi permintaan pasar intelektual Timur Tengah, paling tidak perguruan tinggi di bawah Muhammadiyah, juga berbagai perguruan tinggi Islam yang lain, perlu segera memelopori gerakan penerjemahan buku-buku, artikel, khazanah sosial, budaya dan intelektual Muslim Indonesia yang berkualitas ke dalam bahasa Arab berstandar akademik tinggi, readable bagi kalangan intelektual dan akademisi pengguna bahasa Arab sebagai medium of teaching dan communication-nya. Pengguna bahasa Arab tidak hanya terbatas di wilayah Timur Tengah. Literatur berbahasa Arab akan menyebar ke daratan Eropa dan pusat-pusat studi agama dan keislaman di benua Eropa dan Amerika. Ketika kita beli buku-buku berkualitas akademik tinggi dalam bahasa Arab kadang malah lebih mudah di jumpai di kota Paris dan London, misalnya. Syukur juga dibarengi ke bahasa-bahasa dunia yang lain seperti China, Jepang, Korea selain bahasa-bahasa Barat selain Inggris. Ibaratnya, Muhammadiyah melalu Perguruan Tingginya, seperti pada era Abbasiyah, khalifah al-Ma'mun mendirikan Baitul Hikmah untuk menerjemahkan karya dan manuskrip Yunani ke dalam bahasa Arab dan terus menjadi warisan (legacy) budaya dunia hingga sekarang. Dengan begitu, sharing experience dan transfer of knowledge tentang pengalaman unik-genuine tentang perjumpaan keindonesiaan dan keislaman dapat di akses di Timur Tengah dan beberapa negara pada belahan dunia lain. Ini akan merupakan sumbangan yang tidak ternilai harganya bagi kebudayaan Islam dan peradaban dunia." 42

Kedua,"mendirikan perguruan tinggi yang berkualitas internasional. Amin mengungkapkan bahwa,

42 Amin Abdullah, "Peluang dan Tantangan Internasionalisasi Pemikiran Muhammadiyah," paper dipresentasikan dalam "Tadarus Pemikiran Kaum Muda Muhammadiyah," diselenggarakan oleh JIMM pada 17 Juli 2014 di UMM Malang. 
“...seperti yang dilakukan oleh Gulen Movement, setelah mempunyai jaringan sekolah di seluruh dunia, di 140 negara, mereka kemudian mendirikan perguruan tinggi, Fetih University di Istanbul, yang menggunakan bahasa Inggris sebagai medium of instruction-nya. Jauh lebih dahulu dari Fetih University Istanbul adalah International Islamic University of Malaysia (IIUM) Malaysia. Keduanya adalah contoh yang paling mudah dilihat dan dijadikan banchmarking tentang kemungkinan internasionalisasi pemikiran Islam Indonesia. Mungkin tidak harus langsung satu universitas diubah medium of instruction-nya dalam bahasa Inggris, seperti Fetih university atau IIUM, namun diawali dengan program khusus yang didesain untuk melayani minat mahasiswa internasional dari manapun datangnya. Asrama (dormitory) adalah salah satu syarat penting yang tidak dapat ditinggalkan dan berbagai universitas Muhammadiyah besar telah memilikinya. Memang perlu ada "sayap" persyarikatan dan itu adalah Perguruan Tinggi, yang mulai memikirkan kemungkinan merealisasikan mimpi besar ini." 43

Ketiga, revolusi mental menuju intelektualisme yang berwawasan kosmopolitanistik di antara para intelektual muda di lingkungan JIMM, agar supaya memahami bahwa mereka merupakan bagian dari warga negara dunia. Amin menyampaikan secara lebih lanjut melalui artikulasinya yang sangat reflektif bahwa,

"Cara berpikir, mind set, atau mentalitas generasi muda dan kaum muda intelektual Muslim Indonesia dan pemuda Indonesia pada umumnya, terlebihlebih lagi generasi kaum muda Muhammadiyah, sedikit banyak memang harus berubah. Penekanan mental dan cara berpikir bahwa manusia Indonesia dan umat Islam dimana pun berada adalah bagian tidak terpisahkan dari warga dunia ("world citizenship") adalah tidak bisa tidak. Dengan mentalitas seperti itu - perubahan mental ini tidak mudah- mereka pun pada saatnya akan mau dan rela berkorban dan bekerja disekolah-sekolah dan perguruan tinggi yang mereka dirikan di belahan dunia yang lain, tidak harus mengumpul di negeri sendiri." 44

\section{Corak Intelektualisme Muhammadiyah Masa Depan}

Menurut Mitsuo Nakamura, masa depan Muhammadiyah, termasuk di dalamnya adalah masa depan bidang intelektualisme, bergantung kepada anakanak muda Muhammadiyah, terutama yang tergabung dalam JIMM. Hal yang sama juga diungkapkan oleh Indonesianis terkemuka, Martin van Bruinessen

\footnotetext{
43 Amin Abdullah, "Peluang dan Tantangan Internasionalisasi Pemikiran Muhammadiyah," Ibid.,

44 Amin Abdullah, Ibid.,
} 
dan MC. Ricklefs. Keduanya menyampaikan bahwa, “...masa depan Muhammadiyah jelas tergantung pada kalian (para aktivis-intelektual JIMM)." ${ }^{\text {45 }}$ Para Begawan Muhammadiyah seperti Ahmad Syafii Maarif, Amin Abdullah, Din Syamsuddin, Abdul Munir Mulkhan dan Syafiq A. Mughni, sama seperti para pemerhati Muhammadiyah sebelumnya, telah menyadari dengan baik persoalan ini. ${ }^{46}$ Yang menarik, sejumlah pemikiran rekomendasi untuk Muktamar Muhammadiyah di Makassar, berasal dari ide-ide yang dimatangkan dalam pelbagai forum diskusi JIMM.

Di Muktamar, pelbagai rekomendasi yang diajukan untuk dibahas, dipikirkan, dianalisis dan dilaksanakan berdasarkan pada isu-isu krusial dan fundamental yang kini mengemuka. Tampaklah bahwa sebenarnya Muhammadiyah berwatak progresif, karena tantangan zaman yang hendak dijawab adalah kekinian, demi masa depan umat Islam yang lebih baik di masa mendatang. Tidak keliru seandainya ada sebagian pihak yang menyatakan bahwa visi Persyarikatan bersifat futuristik. Menurut publikasi Suara Muhammadiyah tertanggal 1-15 September 2015, "Rekomendasi Muktamar terbagi menjadi isu keumatan 6 poin (1-6), kebangsaan 7 poin (7-17) dan isu kemanusiaan universal 5 poin (18-22)." Pelbagai poin yang dimaksud, antara lain:

"(1) Keberagamaan yang moderat; (2) Membangun dialog Sunni-Syiah; (3) Substansialisasi agama; (4) Meningkatkan daya saing umat Islam; (5) Membangun budaya hidup bersih; (6) Penyatuan kalender Islam; (7) Toleransi dan kerukunan antar umat beragama (keberagamaan yang toleran); (8) Melayani dan memberdayakan kelompok difabel; (9) Tanggap dan tangguh menghadapi bencana; (10) Membangun budaya egalitarian dan system meritokrasi; (11) Mengatasi krisis air dan energi; (12) Memaksimalkan bonus demografi; (13) Membangun masyarakat ilmu; (14) Menyelamatkan negara dengan Jihad Konstitusi; (15) Perang terhadap narkoba; (16) Gerakan berjamaah melawan korupsi; (17) Perlindungan buruh migran; (18) Adaptasi dan mitigasi perubahan iklim; (19) Perlindungan kelompok minoritas; (20) Eksistensi manusia di bumi; (21) Pemanfaatan teknologi komunikasi; (22) Mengatasi masalah pengungsi." 47

45 Martin van Bruinessen dan MC. Ricklefs, keduanya merupakan Profesor Peneliti di Asian Research Institute (ARI), National University of Singapore (NUS). Ketika ditemui oleh Presidium Nasional JIMM, Pradana Boy ZTF - ketika ia masih menempuh studi doktoral di NUS - dan menanyakan mengenai prediksi akan masa depan Muhammadiyah, keduanya mengatakan, "Masa depan Muhammadiyah tergantung kalian...” Personal interview dengan Pradana Boy ZTF pada 7 Juni 2015.

46 Dalam pelbagai forum intelektual, mereka kerap menyinggung masalah "tampuk kepemimpinan umat" berada di tangan intelektual muda Muhammadiyah.

47 Redaksi Suara Muhammadiyah, "Mencegah Kekerasan Atas Nama Agama," Suara Muhammadiyah 17/100, 1-15 September 2015, h. 8. 
Dari sekian banyak isu tersebut, semuanya berbasis pada paradigma pemikiran Islam yang menaruh perhatian lebih pada spirit progresifitas Islam, liberasi sosial dan aktivisme. Ketiga hal ini masih semakna dengan tiga pilar JIMM seperti yang pernah disinggung Moeslim Abdurrahman. Seiring dengan pemikiran ini, Ketua Pimpinan Pusat Muhammadiyah yang baru, Haedar Nashir mengungkapkan bahwa, penting kiranya memanifestasikan paradigma pemikiran berkemajuan tersebut setidaknya pada tiga program kerja Muhammadiyah. Secara lebih jauh, ia mengungkapkan,

"Kebijakan program Muhammadiyah pada lima tahun kedepan, difokuskan pada tiga hal. Pertama, transformasi sistem organisasi dan jaringan yang maju, professional dan modern. Kedua, berkembangnya sistem gerakan dan amal usaha yang berkualitas utama dan mandiri bagi terciptanya kondisi dan faktorfaktor pendukung terwujudnya masyarakat Islam yang sebenar-benarnya. Ketiga, peningkatan dan pengembangan peran strategis Muhammadiyah dalam kehidupan umat, bangsa dan dinamika global." ${ }^{48}$

Ketiga fondasi yakni spirit progresifitas Islam, liberasi sosial dan aktivisme historis menjadi hal yang terpenting dalam menopang paradigma berpikir di lingkungan intelektual muda Muhammadiyah (JIMM). Tentu saja, ketiga hal tersebut merupakan hasil dari refleksi dan elaborasi intelektual dari nilai-nilai etis Qur'ani yang bersifat universal. Falsafah luhur Islam yang terdiri dari pelbagai nilai etis, merupakan hal yang tidak berubah, utuh, menyeluruh dan senantiasa relevan hingga kapan saja. Kendati pemaknaan atasnya tidak absolut, namun eksistensinya sebagai nilai-nilai etis dapat dirasakan oleh setiap hamba Allah yang merindukan kebenaran ilahiah.

Akan tetapi dalam perspektif praksis intelektual, perlu kiranya pelbagai nilai tersebut dihadapkan dengan realitas kehidupan yang muncul di permukaan. Tidak dapat dibantah bahwa, realitas kehidupan yang kita hadapi senantiasa berubah, sesuai dengan semangat zaman yang mengiringinya. Karena itu, perlu upaya kreatif dalam rangka mengelaborasi hal-hal yang tetap dan universal seperti nilai-nilai yang terus-menerus mengalami perubahan seperti konteks sosio-politik dan kultural umat manusia. Setidaknya terdapat tiga jalan, yakni kesadaran berpikir diagnostik, interpretasi yang kontinyu dan reformulasi gagasan sesuai dengan semangat zaman yang dibungkus dalam berbagai kunci hermeneutis.

48 Haedar Nashir dalam Pidato Pengarahan di hadapan para anggota Muktamar di Balai Sidang Unismuh Makassar, dalam Redaksi Suara Muhammadiyah, "Menghidupkan Matarantai Transformasi," Suara Muhamamdiyah 17/100, 1-15, h. 9. 
Pertama, kesadaran berpikir diagnostik setidaknya berlaku melalui beberapa tahapan, seperti: menyikapi persoalan, mendefinisikan, menganalisis, mencari solusi, mendidik umat untuk menyadari dan segera melakukan sesuatu (gerak strategis) dalam rangka mengimplementasikan jalan-jalan solutif yang sudah dirumuskan. ${ }^{49}$ Kedua, interpretasi yang kontinyu adalah upaya memproduksi makna secara terus-menerus, untuk mempertahankan nilai etis Qur'ani dan nilai kebajikan universal lainnya. Kemudian menyesuaikannya dengan konteks kehidupan sosial kemanusiaan yang sedang dihadapi saat ini. ${ }^{50}$ Ketiga, reformulasi gagasan adalah upaya untuk menghimpun kesepakatan dan kesadaran masyarakat umum, melalui terma elaboratif yang bernilai Qur'ani dan berkemajuan (diterangi pancaran semangat zaman), sehingga mereka mampu membaca apa yang sebenarnya terjadi di lingkungan mereka sendiri dan bertahan dalam realitas persaingan kehidupan global.

Ketiga strategi kreatif di atas sangat penting untuk secara terus-menerus memelihara dan merevitalisasi ketiga fondasi paradigmatik intelektual Muda Muhammadiyah. Hal tersebut tentu saja hadir bukan tanpa landasan. Setidaknya terdapat kredo yang terkenal dalam khazanah tradisi Islam, yang menyebut bahwa Islam itu senantiasa relevan dalam setiap ruang dan waktu (al-Islâmu, shâlih li kulli makân wa zaman). Bahkan sebagian kaum Muslim dengan penuh semangat dan antusiasme yang tinggi, mengungkapkan bahwa Islam itu tinggi dan tiada yang menandingi posisi superioritasnya (al-Islâmu, ya'lu wa la yu'la 'alaih). Istilah shâlih atau relevan dalam setiap putaran zaman, harus bergandeng tangan dengan ikhtiar pencarian makna yang tiada kenal lelah. Artinya, Islam sebagai agama dan nilai, harus mempertimbangkan kondisi sosio-politik dan kultural kehidupan saat ini, sehingga implementasinya menjadi pas, cocok dan relevan. Demikian pula dengan istilah bahwa Islam serba melampaui apabila dihadapkan dengan nilai-nilai kebajikan lain yang berserak di muka bumi ini.

49 Menurut Azhar Ibrahim dalam narasinya, diungkapkan bahwa “(a) The ability to identify and being affected by a particular problem of issue confronting the society; (b) The ability to determine and define the problems that emerged; (c) The ability to analyse the problems from various dimensions; (d) The ability to offer viable solutions to solve the problems and (e) The courage to challenge the existing ideas that have caused the aggravation of the problems confronted." Narasi ini sangat sesuai dengan strategi kreatif dalam rangka merevitalisasi fondasi paradigma berpikir di lingkungan JIMM. Lihat Azhar Ibrahim, "The Making of Progressive Religion," Islam, Religion and Progress: Critical Perspective (Singapore: The Reading Group, 2006), h. 24; Lihat juga Karl Mannheim, Freedom, Power and Democratic Planning (London: Routledge and Kegan Paul, 1951), hal. 4.

50 Tariq Ramadan, The Quest for Meaning: Developing a Philosophy of Pluralism (London: Allen Lane, 2010). 
Pelampauan ini akan benar-benar menjadi kenyataan apabila umat Islam sendiri mampu memenangkan persaingan peradaban. Melalui bahasa yang khas Muhammadiyah, maka harus ada ikhtiar yang sungguh-sungguh sehingga terwujud "Masyarakat Islam yang Sebenar-benarnya", khususnya dalam konteks kehidupan global.

Karena itu, apabila terdapat pertanyaan mengenai bagaimana corak intelektualisme Muhammadiyah masa depan? Maka tengoklah perkembangan intelektualisme di JIMM. Namun pertanyaan selanjutnya, bagaimana corak intelektualisme setelah JIMM? Jawabannya berkisar mengenai bagaimana lingkungan intelektualisme tersebut mengupayakan kaderisasi, dalam rangka menghadapi masa depan yang tentu saja berbeda dengan segala realitas yang dihadapi saat ini. Misalnya, ketika nanti manusia benar-benar berkewarganegaraan dunia (world citizenship), lalu berhadapan dengan kemajuan sains dan teknologi yang benar-benar berbeda dan lebih canggih, perkembangan industrialisasi yang semakin pesat dan menyesakkan bumi, lingkungan hijau yang mulai terkikis habis, persediaan minyak dan hasil tambang yang musnah, pelbagai krisis multidimensional kehidupan masa depan, pada saat itulah akan muncul generasi baru yang harus memiliki kapasitas intelektualitas sesuai dengan zamannya. Dalam konteks ini, mungkin prediksi Nabi Muhammad mengenai bahwa setiap seabad akan muncul generasi baru ada benarnya. Karena, prediksi Nabi tersebut menjadi hal yang masuk akal secara sosiologis. Pada akhirnya, marilah kita renungkan pernyataan dari Karl Mannheim yang sangat relevan berikut ini,

"One can understand the contemporary world in its rapid change only if one learns to think sociologically, if one is capable of understanding changes in ways of human behavior by reference to the changing conditions of society. This, however, also requires acquaintance with recent findings in psychology and philosophy." 51

\section{Penutup}

Sebagai jejaring kultural di bidang intelektualisme di lingkungan Muhammadiyah, hadirnya JIMM merupakan fenomena sosial yang sangat menarik dan penting untuk dikaji secara serius. Pasalnya, JIMM dianggap sebagai penanda lahirnya generasi baru yang akan menggantikan struktur organisasi induknya,

51 Karl Mannheim, "On the Diagnosis of Our Time," From Karl Mannheim, diedit oleh Kurt H. Wolff dengan kata pengantar oleh Volker Meja dan David Kettler, New Brunwick, NJ.: Transaction Publishers, 1993, h. 95. 
yakni Muhammadiyah. Dalam konteks ini, hadits bahwa akan lahir generasi pembaharu setiap seratus tahun sekali, ternyata juga sangat masuk akal apabila ditinjau melalui sudut pandang sosiologis.

Periode pasca Satu Abad Muhammadiyah sejak kelahirannya (1912), JIMM harus berhadapan dengan konteks kehidupan global, di mana ruang pergaulan sosial masyarakat global telah terbuka. Masalah penting lain yang harus dihadapi oleh umat Islam, khususnya JIMM adalah adanya arus besar neo-liberalisme yang mengendalikan seluruh persaingan global. Dalam situasi ini, JIMM harus mempertimbangkan konsep politik identitas, yang mampu mengatasi segala kesulitan dan kompleksitas negara bangsa. Oleh karena itu bagi JIMM, kosmopolitanisme memiliki arti penting. Kosmopolitanisme bukan sekedar perspektif yang mampu mengafirmasi pentingnya konsep kewarganegaraan dunia, tetapi juga strategi dakwah yang berupaya untuk memenangkan pertarungan dalam konstalasi peradaban global.

Dalam konteks persaingan ekonomi politik misalnya, saat ini negara-negara dunia pertama menjadi pihak yang senantiasa memainkan peran, terutama terhadap negara-negara dunia ketiga. Dengan demikian, nilai-nilai etis Islam yang universal bagi JIMM harus menjadi fondasi bagi agenda kontekstualisasi Islam di hadapan persaingan global. Kontekstualisasi Islam bagi JIMM tereformulasikan dalam tiga nilai paradigmatik, yakni Islam yang berkemajuan, liberasi sosial dan aktivisme historis. Ketiga nilai itulah yang harus tetap ada, sembari secara terus-menerus mendiagnosa konteks kehidupan sosio-politik dan kultural masyarakat, seiring dengan bergulirnya zaman. Dengan demikian, JIMM juga memiliki tanggungjawab moral, untuk mengupayakan kaderisasi dalam rangka mempersiapkan generasi intelektual masa depan, yang tanggap dan tidak gagap terhadap segala tuntutan zaman.[]

\section{Bibliografi}

Abdullah, Amin, "Ihsan dan Tasawwuf dalam Khazanah Pemikiran Islam (3)," Suara Muhammadiyah, Edisi No. 18 (98) (16-30 September 2013), h. 22-23. Abdullah, Amin, "Paradigma Tajdid: Muhammadiyah sebagai Gerakan Islam Modernis-Reformis," Media Inovasi: Jurnal Ilmu dan Kemanusiaan, Edisi

Khusus Muktamar Satu Abad Muhammadiyah (2010), h. 20-25.

Abdullah, Amin, "Peluang dan Tantangan Internasionalisasi Pemikiran Muhammadiyah," paper dipresentasikan dalam "Tadarus Pemikiran Kaum 
Muda Muhammadiyah," diselenggarakan oleh JIMM pada 17 Juli 2014 di UMM Malang.

Abdurrahman, Moeslim dalam "Krisis Sosial, Krisis Politik, dan Krisis Bangsa Majemuk," Suara Tuhan, Suara Pemerdekaan (Yogyakarta: Kanisius, 2009), h. 17-44.

Abdurrahman, Moeslim dalam Kuliah Umum di Padepokan HW Malang pada 13 Maret 2010. Lihat transkrip kuliahnya dalam https:// kataitukata.wordpress.com/2012/07/06/ kuliah-dr-moeslim-abdurrahman/ (diakses pada 7 Juni 2015).

Abdurrahman, Moeslim dalam Kuliah Umum, "Menggugat Modernitas Muhammadiyah,” yang diselenggarakan oleh Pusat Studi Islam dan Filsafat (PSIF), 13 Maret 2010, di UMM, Malang.

Abdurrahman, Moeslim, "Epilog," Islam sebagai Kritik Sosial, Jakarta: Erlangga, 2003, h. 168-205.

Abdurrahman, Moeslim, "Islam dan Keragaman Budaya," dalam Denny Mizhar dan Hasnan Bachtiar (eds.), Merajut Kebersamaan dalam Keragaman, Malang: RESIST Literacy dan Cordaid, 2010, h. 3.

Abdurrahman, Moeslim, "Memperebutkan Kebenaran Firman," Muhammadiyah Progressif: Manifesto Pemikiran Kaum Muda, Jakarta: JIMM dan LESFI, 2007, h. xxiii.

Abdurrahman, Moeslim, "Munculnya Kesadaran Kritis Ber-Muhammadiyah: Sebuah Pengantar," dlm. Pradana Boy ZTF dan M. Hilmi Faiq (eds.), Kembali ke al-Qur'an Menafsir Makna Zaman: Suara-suara Kaum Muda Muhammadiyah, Malang: UMM Press, 2004, h. vii-xviii.

Abdurrahman, Moeslim, "Pengantar," Suara Tuhan Suara Pemerdekaan, Yogyakarta: Kanisius, 2009, h. 11.

Abdurrahman, Moeslim, "Tafsir atas Wahyu: Mengedepankan Transformasi, Bukan Reformasi," Suara Tuhan, Suara Pemerdekaan, Yogyakarta: Kanisius, 2009, h. 168-184.

Alfian, Islamic Modernism in Indonesian Politics: The Muhammadijah Movement during the Dutch Colonial Period (1912-1942), Ph.D. Thesis, The University of Wisconsin-Madison, 1969.

Alief, Mohamad Ishsan, "Political Islam and Democracy: A Closer Look at the Liberal Muslims," Wilson Center: Asia Program Special Report, No. 110, 2003, h. 14. 
Bachtiar, Hasnan, "Neo Sufisme Muhammadiyah dalam Artikulasi Teoretika," Neo-Sufisme Muhammadiyah, Malang: UMM Press, 2015.

Baidhawy, Zakiyuddin, "Merujuk al-Qur'an Menafsir Cita-Cita Muhammadiyah," Makalah dipresentasikan dalam "Tadarus Pemikiran Kaum Muda Muhammadiyah: Muhammadiyah dan Gerakan Sosial Baru” yang diselenggarakan oleh Universitas Muhammadiyah Malang bekerjasama dengan Jaringan Intelektual Muda Muhammadiyah, Malang 17-19 Juli 2014.

Baidhawy, Zakiyuddin, Teologi Neo al-Maun: Manifesto Islam Menghadapi Globalisasi Abad 21, Yogyakarta: Civil Islamic Institute, 2009.

Boy ZTF., Pradana, "JIMM: Sebuah 'Teks' Multitafsir," Era Baru Gerakan Muhammadiyah, Malang: UMM Press dan al-Ma'un Institute Jakarta, 2008, h. 47-51.

Boy ZTF., Pradana, M. Hilmi Faiq dan Zulfan Barron (eds.), "Dianggap Liberal, JIMM Diadili," Era Baru Gerakan Muhammadiyah, Malang: UMM Press dan al-Ma'un Institute Jakarta, 2008, h. 211-2.

Burhani, Ahmad Najib, "Internasionalisasi Muhammadiyah," Tanwir: Majalah Kauman, Ikatan Mahasiswa Muhammadiyah, Edisi Maret-April 2015, h. 46.

Burhani, Ahmad Najib, "JIMM: Pemberontakan Generasi Muda Muhammadiyah terhadap Puritanisme dan Skripturalisme Persyarikatan,” dlm. Neng Dara Afifah (ed.), Reformasi Gerakan Keislaman Pasca Orde Baru: Upaya Merambah Dimensi Baru Islam, Jakarta: Balitbang Depag RI, 2006, h. 352-399.

Burhani, Najib, "Internasionalisasi Gerakan Muhammadiyah," Suara Muhammadiyah, 11/100, 1-15 Juni 2015.

Din Syamsuddin pada pembukaan forum "Tadarus Pemikiran Kaum Muda Muhammadiyah," diselenggarakan oleh JIMM pada 17 Juli 2014 di UMM Malang.

Ibrahim, Azhar, "Against 'Islam Liberal': A Reactionary Discourse of Religious Conservatives and the Response of Progressives," Contemporary Islamic Discourse in the Malay-Indonesian World: Critical Perspectives, Malaysia: SIRD, 2013, h. 241.

Ibrahim, Azhar, "The Making of Progressive Religion," Islam, Religion and Progress: Critical Perspective, Singapore: The Reading Group, 2006, h. 24. 
Kuntowijoyo, "Pengantar: Jalan Baru Muhammadiyah," dlm. Abdul Munir Mulkhan, Islam Murni dalam Masyarakat Petani (Yogyakarta: Bentang, 2000).

Maarif, Ahmad Syafii dalam Kuliah Umum yang bertajuk "Gagasan Islah dan Tajdid Muhammadiyah,” yang diselenggarakan oleh Islamic Renaissance Front (IRF) Malaysia, di Graha Pemuda Sri Hartamas, Kuala Lumpur, Malaysia, pada 21 Juni 2014.

Maarif, Ahmad Syafii, "Keniscayaan Kebebasan Berfikir dalam Muhammadiyah," dlm. Ajang Budiman dan Pradana Boy ZTF. (eds.), Menggugat Modernitas Muhammadiyah: Refleksi Satu Abad Perjalanan Muhammadiyah, Jakarta: Best Media dan PSIF UMM Malang, 2010, h. 132.

Mannheim, Karl, Freedom, Power and Democratic Planning, London: Routledge and Kegan Paul, 1951, hal. 4.

Mannheim, Karl, Ideology and Utopia, London: Routledge \& Kegan Paul, 1976. Mannheim, Karl, "On the Diagnosis of Our Time," From Karl Mannheim, diedit oleh Kurt H. Wolff dengan kata pengantar oleh Volker Meja dan David Kettler, New Brunwick, NJ.: Transaction Publishers, 1993, h. 95

Mulyadi, Sukidi, "Menjadi Muslim Pluralis: Pergulatan Mencari Kebenaran dan

Tuhan," Muhammadiyah Progressif: Manifesto Pemikiran Kaum Muda, Jakarta: JIMM dan LESFI, 2007, h. 426.

Munir, Lily Zakiyah, "Agendas for 'Liberal Islam': Contending Radicalism, Promoting Interfaith Dialogue and Pursuing the Rights of the Poor," ICIP Journal, Vol. 2, No. 3, 2005, h. 7.

Nakamura, Mitsuo di http://www.umm.ac.id/id/umm-news-4188-ikhtiarintelektual-umm-jimm-dipuji-dua-peneliti-asing.html (diakses pada 8 Juni 2015).

Nashir, Haedar dalam Pidato Pengarahan di hadapan para anggota Muktamar di Balai Sidang Unismuh Makassar, dalam Redaksi Suara Muhammadiyah, "Menghidupkan Matarantai Transformasi," Suara Muhammadiyah 17/ 100, 1-15, h. 9.

Personal interview dengan Abdul Munir Mulkhan, 7 Juni 2015 di Malang.

Personal interview dengan Amin Abdullah, 17 Juli 2014 di Malang.

Personal interview dengan Azhar Ibrahim Alwee pada 1 Desember 2014 di Malang dan 26 Februari 2015 di Singapura.

Personal interview dengan Pradana Boy ZTF pada 7 Juni 2015. 
Personal interview dengan Pradana Boy ZTF pada Kamis, 3 September 2015.

Personal interview dengan Pradana Boy ZTF, 17 Juli 2014 di Malang.

Personal interview dengan Pradana Boy ZTF., pada 7 Juni 2015 di Batu, Malang.

Personal interview dengan Zuly Qodir pada 31 Oktober 2014, di Solo.

Qodir, Zuly, "Muhammadiyah dan Gerakan Islam Non-Mainstream," paper dipresentasikan dalam "Tadarus Pemikiran Kaum Muda Muhammadiyah," diselenggarakan oleh JIMM pada 17 Juli 2014 di UMM Malang.

Rahardjo, Dawam dalam Seri Kuliah Umum PSIF yang bertajuk "Politik Dunia Islam yang Bergejolak,” pada 24 April 2015, di Universitas Muhammadiyah Malang.

Rahman, Fazlur, Revival and Reform in Islam: A Study on Islamic Fundamentalism, Oxford: Oneworld Publications, 2009.

Ramadan, Tariq, Islam, the West and the Challenges of Modernity, Leicester, UK: The Islamic Foundation, 2001.

Ramadan, Tariq, The Quest for Meaning: Developing a Philosophy of Pluralism, London: Allen Lane, 2010.

Ramadan, Tariq, Western Muslims and the Future of Islam, New York: Oxford University Press, 2004.

Redaksi Suara Muhammadiyah, "Mencegah Kekerasan Atas Nama Agama," Suara Muhammadiyah 17/100, 1-15 September 2015, h. 8.

Rehman, Scheherazade S. dan Hossein Askari, "How Islamic are Islamic Countries?," Global Economy Journal, Vol. 10, Issue 2 (2010), h. 1-37.

Setiaji, Bambang, "Mewujudkan Peta Jalan Internasionalisasi Muhammadiyah," Jawa Pos 14 April 2015 